\title{
Joventut i procés d'autonomia: desmitificar per acompanyar
}

\author{
Anna Robles i Miserachs \\ Màster Interuniversitari en Joventut i Societat, Universitat de Girona \\ aroblemi@hotmail.com
}

Resum: La tendència generalitzada que considera l'autonomia com a finalitat de gran part dels objectius en politiques de joventut ba sobredimensionat el concepte fins a mitificar-lo. Acotar-ne la definició, revisar els diversos noms que rep el mateix encàrrec així com contextualitzar el treball amb joves als efectes de la globalització, l'impacte social de les TIC i un mercat laboral de dificil accés permet segregar els trets més il.lusoris de la pretesa autonomia adulta dels elements veritablement útils per a l'atenció $i$ acompanyament de joves en el seu procés d'autonomia. Es tracta d'una reflexió que recopila diversos plantejaments teòrics entorn del concepte d'autonomia $i$ que desemboca en una proposta pràctica que, tot i estar basada en l'experiència en l'atenció a joves extutelats, pretén plantejar aspectes vàlids per a l'àmbit de la joventut en conjunt.

Paraules clau: autonomia, emancipació, ciutadania, transició a la vida adulta, acompanyament

Abstract: The general tendency to consider autonomy to be the aim of most of the objectives of youth policies has over-estimated the concept to such an extent that it has now become a legend. Refining its definition, reconsidering the many labels attached to it, and contextualising the work done with young people on globalization, the social impact of ICT and the increasing problems of finding work enable the misleading features of the aspiration for adult autonomy to be distinguished from the truly useful items for the care and support of young people in their quest for independence. The paper is a reflection that brings together various theoretical approaches to the concept of autonomy and leads to a practical proposal which, although based on the experience of dealing with young people who used to be under tutelage, aims to raise valid issues in the field of youth as a whole.

Keywords: autonomy, emancipation, citizenship, transition to adulthood, accompanying 


\section{Introducció}

Al llarg de la reflexió sobre la relació entre joventut i societat hi ha un aspecte que, com l'au fènix, ressorgeix de les cendres de cada disciplina que l'aborda i de la qual reneix una imatge mitològica comuna, que rep diferents noms, canvia d'aparença $i$ està disseminada en conceptes propers. Seguint la línia imaginària que els uneix, es dibuixa una constel-lació de conceptes que proposen un encàrrec semblant en el treball amb joves i que en matèria de joventut es transmet de teòrics a tècnics i de tècnics a teòrics tot engendrant el mite de l'autonomia.

Al Diccionari de la mitologia grega i romana, Grimal defineix el mite en tant que «una narració que fa referència a un ordre del món anterior a l'ordre actual i destinat no tant a explicar una particularitat local i limitada [... ], sinó una llei orgànica de la naturalesa de les coses». El mite atribueix un ordre natural i es transmet habitualment sense qüestionar-se massa. El mite és, a més a més, una història fabulosa en què apareixen éssers sobrenaturals que actuen per sobre dels mortals, éssers considerats inferiors que conviuen amb els seus encerts, els seus errors i les seves complexes relacions. S'atribueix així una dimensió sagrada als esdeveniments fabulats que es barregen amb la història i que constitueixen relats que trobem a la base de religions, que estableixen dogmes i són protagonitzats per déus, profetes i herois.

Si bé no trobem cap relat en què aparegui cap ésser mitològic capaç d'atorgar autonomia, es pot considerar l'autonomia un mite en el sentit que ha estat mitificada. El problema de partida sobre el qual es treballarà és el fet que el concepte d'autonomia està molt de moda, śutilitza en diferents àmbits i de forma sistemàtica, probablement per referir-se a diferents perspectives que corresponen a diversos objectius. En la línia del que proposa Meirieu a Frankenstein Pédagogue caldria desconfiar del concepte d'autonomia per l'ús indiscriminat que sén fa i que el buida de contingut, partint de la hipòtesi que es tracta d'un mite, d'un ideal, d'un principi que pot orientar l'acció educativa, però que cal ser considerat en la justa mesura i desproveir-lo dels matisos més il-lusoris i simplistes per tal de concretar els aspectes més eficients i creïbles per al treball amb joves.

La pregunta sorgeix també amb relació al principal encàrrec que l'administració fa al Servei de Seguiment, Acompanyament i Suport al Jovent Extutelat; un equip creat per atendre joves que havien estat tutelats per l'administració, 
que acaben de complir la majoria d'edat i als quals es proposa acompanyar per tal de promocionar-ne l'autonomia. Es tracta d'oferir suport econòmic $i$ un seguiment educatiu perquè joves de 18 a 21 anys planifiquin i iniciïn o continuïn un procés d'autonomia. Partint del pacte recollit en un pla de treball, s'inicia el cobrament i seguiment de la prestació econòmica per a joves extutelats per tal de revisar l'assoliment d'objectius i anar plantejant noves fites cada cop cap a un major nivell d'emancipació familiar i de l'administració. Des dels inicis d'aquest servei, s' ha anat elaborant una metodologia apuntant sempre cap a l'objectiu últim de l'autonomia, tasca que ha plantejat diverses discussions i contradiccions que porten a qüestionar el concepte.

El tema de l'autonomia apareix sovint en serveis adreçats als joves. Per això convé analitzar-lo en profunditat procurant no ubicar-lo en una concepció tan allunyada de la realitat en què s'atendrà els joves que acabi sent, exclusivament, un treball digne de déus, herois i titans, tant pel rol dels professionals que l'hauran de sostenir com per als destinataris d'una labor tan àmplia.

\section{Un encàrrec digne de déus, herois i titans}

El terme autonomia pren diversos sentits en moltes disciplines, entre les quals la filosofia, la biologia, la física i química, les matemàtiques, la política o el dret. De les diferents accepcions de l'autonomia, cal destacar que en pedagogia és un terme que constitueix potser un dels principals objectius de l'educació. Cal saber, però, quin concepte d'autonomia opera i quines implicacions suposa per tal de definir i acotar un dels principals encàrrecs que la societat fa a gran part dels agents educatius.

Socialment, moltes vegades es relaciona la promoció de l'autonomia amb l'àmbit d'atenció a la discapacitat. Una de les lleis que revisa el concepte d'autonomia és precisament la que pretén establir la definició i marges de la dependència. La Llei 39/2006, anomenada "de la dependència", estableix que l'autonomia és "la capacidad de controlar, afrontar y tomar, por propia iniciativa, decisiones personales acerca de cómo vivir de acuerdo con las normas y preferencias propias así como de desarrollar las actividades básicas de la vida diaria”. ${ }^{1}$ Aquesta és una definició molt avesada a qüestions pràctiques, de la

1. Article 2n de la Llei 39/2006, de 14 de desembre, de promoció de l'autonomia personal $i$ atenció a les persones en situació de dependència. 
quotidianitat, que fan referència a la cura personal i a la possibilitat de realitzar activitats diàries sense ajuda d'altres persones i, per tant, estableix una interpretació massa restringida del concepte mitològic al qual s'invoca ara.

Lautonomia suposa una relació que generalment remet a la llibertat i la responsabilitat, i que generalment també soposa a la dependència, el determinisme i la irresponsabilitat. Revisar l'oposició introdueix elements que matisen i retornen la complexitat al concepte d'autonomia, especialment amb relació a la dependència. En aquest sentit, val al pena recuperar el plantejament que Romaní exposa en l'obra que realitza una lectura antropològica de l'ús de les drogues:

El hombre es un ser dependiente por naturaleza, y digo por naturaleza, no como una expresión, sino de manera precisa, por su constitución biológica: es un animal con una programación genética abierta, con una orientación muy general de sus instintos, que es moldeado de una manera decisiva por su cultura, la cual incorpora (embodiment) a través de la interacción social y el aprendizaje, gracias principalmente al largo período de crecimiento que le caracteriza (Romaní, 2004: 59).

A continuació, anomena un reguitzell de dependències que configuren la quotidianitat. La dependència és, més enllà dels efectes farmacològics d'una substància $\mathrm{i}$ en una observació extrapolable a altres àmbits com el mateix antropòleg planteja,

un constructo sociocultural en el que confluyen procesos de identificación, de construcción del yo, estrategias de interacción, negociación de rol, en fin, todo un entramado de relaciones sociales y expectativas culturales que contribuyen a la construcción del sujeto y a través de las que éste orienta su existencia (Romaní, 2004: 60).

De fet, ningú no és completament autònom, s'ha de reconèixer certa dependència afectiva de les relacions. Com tampoc no hi entenem en tot i depenem del saber dels altres, cal saber fins a on un problema el resol un/a mateix/a i en quin nivell recórrer a les amistats, els familiars o els dispositius socials, com es tendeix en qüestions de salut, per exemple. Per tant, adquirir autonomia, en el sentit d'esdevenir adult, no està exempt de dependència i caldria mesurar fins a quin punt no s'hauria d'interpretar a la inversa, de com el vincle amb els altres és el que permet fer-se a un mateix. En tot cas, es pot considerar l'autonomia 
com a procés a través del qual els joves comencen a deixar de ser completament dependents i limitats en diferents graus per a la presa de decisions, adquireixen els recursos i desenvolupen les capacitats que els permetran conquerir progressivament espais d'autonomia individual. Precisament aquells espais que els seran necessaris per accedir a la relativa independència tal com sentén que ha de ser la vida adulta.

És clar que "les dificultats d'integració social són fruit d'una dinàmica de doble direcció. D'una banda, hi ha els individus, que tenen o no dificultats per respondre a les expectatives socials, però, de l'altra, hi ha la societat, que facilita o dificulta aquest procés d'inserció social” (Berga, 2006: 27). En aquest sentit, "los jóvenes actuales se encuentran atrapados en una situación de dependencia que no sólo dificulta enormemente su incorporación a la sociedad adulta sino que termina expulsándoles en la práctica de la esfera pública" (Benedicto i Morán, 2002: 20). Proposa aleshores que "en vez de seguir centrando como hasta ahora toda la discusión sobre los problemas de los jóvenes y su situación de dependencia hay que preguntarse como podemos formar sujetos autónomos, con voz propia en la sociedad política y con capacidad para intervenir en la esfera pública" (Benedicto i Morán, 2002: 23). Benedicto planteja una lectura a la inversa, relectura que val la pena transferir a altres oposicions.

Des de la filosofia i la psicologia evolutiva es defineix l'autonomia com la capacitat de donar-se normes a un mateix sense influència de pressions externes o internes, i s'estableix per oposició a l'heteronomia de la voluntat definida per Kant. La voluntat pot estar condicionada per la raó (condició per a l'autonomia) o per la inclinació (condició de l'heteronomia). Per inclinació s'entén les motivacions que sorgeixen per inèrcia, amb relació "al que s'acostuma a fer" o bé al que es més pulsional. L'heteronomia és antiautonomia, ja que satisfer els apetits et fa menys lliure en la mesura que per aconseguir-los es topa amb les constriccions socials i, per tant, requereix una negociació i adaptació que es desplaça del terreny de la pròpia voluntat. L'heteronomia és el contrari de l'autonomia en la mesura que allò que et proposes queda filtrat per les normes socials i no pas per les normes que un mateix acredita. Per això l'autonomia no podria entendrés com la capacitat exclusivament individual de decidir sobre una norma (seria, si no, el contrari de la norma), sinó que consisteix més aviat a optar per les normes i valors que hom consideri vàlids. Es tracta, doncs, d'una 
qüestió de consentiment i elecció, de criteri que oscillla entre la vessant universal i la vessant individual.

Des de la teoria psicològica, Piaget planteja l'oposició en els termes següents: en el pensament heterònom, les regles són objectives i invariables, s' han de complir literalment i la base de la norma és l'autoritat superior de l'adult; en el pensament autònom, les regles parteixen d'un acord; per tant, es poden modificar, interpretar i plantejar excepcions i discussions, així com la base de la norma és l'acceptació, per la qual la norma ha de ser profundament entesa.

Sembla, doncs, que per parlar d'autonomia pròpiament cal una òptica situada entre els extrems de la dependència o l'heteronomia a un punt subtil, de trobar un equilibri, un de propi i elaborat i que Meirieu descriu poèticament en aquest fragment:

Plus question ici de chercher comment satisfaire les désirs de l'adulte pour se laisser aller finalement à ses propres caprices. On change de registre. On accède à quelque chose d'étrange, de nouveau, quelque chose comme «la volonté». «Se mettre en je.» Ne plus être simplement le «tu» de quelqu'un d'autre, docile ou révolté mais infiniment dépendant. Ne plus être, non plus, son propre «tu», cédant à l'excitation du moment, se donnant l'illusion de la liberté quan on est simplement prisonnier de ses impulsions immédiates. Sortir de l'imaginaire où rien n'est possible parce qu'on croit que tout est possible [...] ajuster son costume, jeter un regard serein autour de soi, oublier un instant ses peurs et ses fantasmes, penser très fort à ce que l'on fait, avaler sa salive et... faire le pas (Meirieu, 1996: 32).

Apareix de nou la qüestió de la dependència, del deixar de ser infant per tendir a ser adult, i obre la porta de la possibilitat, de la presa de decisions i de portar a terme allò que hom es proposa. Un objectiu que s'ha planificat i incentivat en diverses disciplines, motiu pel qual s'han generat un reguitzell de termes que, amb intencions semblants, volen anomenar el punt d'inflexió, l'encreuament, el principi d'un rol i una etapa que transcorre durant la joventut i a la qual s'han atribuït diverses denominacions. Se l'anomena emancipació, es parla de participació, śapunta a l'accés a la ciutadania o es té en compte la transició a la vida adulta. 


\section{Autonomo constellatio}

Benedicto planteja la pregunta amb relació al fet que l'emancipació hagi de ser una qüestió clau en les polítiques juvenils i assenyala que

La emancipación siempre es clave en el proceso de transición juvenil, pero hay que distinguir entre dos aspectos: la emancipación y la autonomía. El objetivo de las políticas juveniles debe ser la búsqueda autonomía juvenil. Es verdad que el momento de desarrollar ésta es el de la emancipación, pero el objetivo debe ser la autonomía. ¿Por qué? Porque a veces el objetivo de la política juvenil es la emancipación, y las instituciones se ponen contentas cuando baja la edad a la que los chicos se van de casa, pero lo importante no es que se vayan de casa sino en qué condiciones se van de casa. El objetivo fundamental debe ser la búsqueda de autonomía, que a veces se consigue en una especie de semidependencia de los padres.

Per tant, situa a diferents nivells emancipació i autonomia; la primera respon a una independència econòmica de subsistència $i$ la segona com a projecte més sòlid i més ampli. A més a més, torna el tema de la dependència, inherent a mitjà termini per tal que es produeixi una completa emancipació.

Reguillo convida a treballar per habilitar els joves perquè desenvolupin un paper actiu. El treball educatiu i social amb joves ha de "donar emancipació", és a dir, que es destinin esforços a capacitar-los perquè puguin ser actors i actrius precisament $\mathrm{amb}$ la intenció que sàpiguen intervenir en les dinàmiques socials que generen exclusió. En aquest sentit, s'ha treballat la qüestió de la participació i convé recollir-ne algunes consideracions. Els joves sembla que tendeixin a desvincular-se de l'associacionisme prescindint de les institucions per adoptar noves formes de participació ciutadana. La societat condemna l'apatia, indiferència i manca de participació del jovent en el teixit social amb instruments estadístics que quantifiquen les accions d'uns determinats models de participació. En aquest sentit, convé reconèixer que els joves no han deixat de participar activament en el discurs social, sinó que les seves actuacions han estat invisibilitzades per un concepte anacrònic d'associacionisme institucionalitzat. Reguillo recull tres exemples de noves modalitats de participació social dels joves: moviment altermundista, globosfera i la tendència a involucrar-se en causes $i$ no en moviments. Aquestes modalitats poden passar inadvertides en tant que redefineixen els paràmetres espaciotemporals de l'associacionisme; és a dir, una 
identitat collectiva pot generar acció social des d'un pla virtual, la trobada i la difusió d'aquest col-lectiu pot produir-se virtualment ampliant les possibilitats de l'espai i el temps. Així, doncs, assistim a un seguit de canvis i transformacions en les diferents dimensions de la participació juvenil que s'han de tenir en compte. La participació juvenil sembla desplaçar-se cap a contextos informals, on els vincles vivencials i existencials dels individus es configuren com a motor d'acció. La proposta de futur és explorar nous horitzons que els propis joves estan generant al marge de les associacions institucionalitzades. Els ciutadans, entre els quals el jovent, cada cop més, intervenen i participen en funció de la problemàtica o del tema social que sabordi, entren i surten, conformen collectius que saglutinen i es dispersen successivament.

La participació dels joves en el segle xxi requereix un canvi de paradigma. Així mateix, implica recuperar un cert poder. També s'ha posat de moda el concepte d'apoderament o empowerment, especialment en l'àmbit empresarial. Dintre del àmbit dels recursos humans, s'entén com una manera d'incentivar els talents i potencialitats dels treballadors pel seu bé i el de l'empresa. En l'àmbit social, es refereix a quelcom diferent, és "el proceso de aumentar el poder personal, interpersonal y comunitario o político de modo que los individuos, las familias, y las comunidades puedan actuar por si mismos para mejorar sus situaciones" (Gutiérrez, 1994: 202). Consisteix en el procés mitjançant el qual śassoleix una presa de consciència i augment de poder propi en el qual es formulen uns objectius i es desenvolupen els mitjans per aconseguir-los. La perspectiva de l'empowerment es basa en la interacció social en el sentit que és la capacitat de relacionar-se amb els altres el que atorga poder. Tenint en compte que la interacció social es desenvolupa entre el poder i la falta de poder, proposa recuperar la quota de poder que es té a l'abast. Depenent de com es gestionin les relacions es produeix cert apoderament $\mathrm{i}$ alhora afecta l'autonomia, la identitat i la ciutadania. El concepte d'empowerment

establece una significativa diferencia entre el poder como dominación frente al poder como capacitación o fortalecimiento. Es decir, frente a la probabilidad de que las órdenes sean obedecidas por un grupo de personas, desde la perspectiva del empowerment, se apoya la idea de un poder que emerge desde el interior. Es el poder de la habilidad, de la elección y el compromiso, es creativo y transformador pero no es un poder controlador. En definitiva, la persona con poder tiene la habilidad de ejercer influencia sobre el curso de su propia 
vida, y la posibilidad de trabajar con otros para modificar aspectos de la vida social (Segado 2011).

Lacció en l'àmbit social remet igualment al concepte d'accés a la ciutadania. Repassant els últims 30 anys de les polítiques de joventut a Catalunya i les fases que s'han anat produint, es pot seguir evolució del concepte d'autonomia, bàsicament amb relació a les polítiques d'emancipació, i la presència que té en qüestions de joventut. Un cop superada la fase inicial de les polítiques de lleure juvenil, s'ha passat d'entendre els processos d'integració social partint de l'emancipació a orientar les polítiques de joventut amb la intenció que, a canvi que els joves no reclamin els seus drets en el mercat laboral o de l'habitatge, séls convida a ocupar un espai més plaent i de menys responsabilitat, les anomenades polítiques d'afirmació. També s'han promogut polítiques que combinen ambdues tipologies, tenint en compte que els joves arriben a ser ciutadans per una combinació d'experiències juvenils amb experiències cíviques. Actualment immersos en el paradigma de les polítiques d’afirmació de la plena ciutadania, cal promoure polítiques capaces de facilitar als joves l'assumpció de responsabilitats envers la col-lectivitat.

En aquest sentit, Benedicto aporta valuosos elements, ja que l'accés a la ciutadania es pot considerar una vessant o una tipologia de la promoció de l'autonomia. La proposta gira entorn del desenvolupament de les capacitats per esdevenir protagonista de l'esfera pública i śaprofundeix en el llibre del mateix professor de Sociologia i Política amb el títol La construcción de una ciudadanía activa entre los jóvenes.

\section{Tal com Benedicto i Morán valoren,}

en un momento histórico en que los marcadores de la vida adulta se hacen cada vez más ambiguos, la ciudadanía parece ser una herramienta conceptual válida para analizar y comprender la incorporación de los jóvenes a la vida de los adultos. La conclusión a la que nos lleva esta forma de plantear la cuestión es que el ciudadano se define más por el lugar social que ocupa, el que corresponde al adulto libre de dependencias familiares, que por la relación que establece con la comunidad y las prácticas que lleva adelante. Por ende, la juventud se convierte en una etapa a superar para poder llegar a la etapa adulta, la del ciudadano completo (Benedicto, 2002: 41). 
És a dir que, si bé l'assoliment de la plena ciutadania pot establir la diferència entre aquells que ocupen una posició adulta per oposició als que són encara dependents, cal matisar en què consisteix realment un exercici real i complet de ciutadania, més enllà de les capacitats econòmiques i materials per ser autosuficient. Així mateix, afegeix que

El reconocimiento formal y subjetivo de los derechos y obligaciones, la adquisición de las competencias necesarias para comprender los asuntos de la esfera pública y el desarrollo de las virtudes cívicas necesarias para sentirse parte de una comunidad constituyen, de manera muy sucinta, los tres tipos de recursos que se necesitan para incorporarse a la institución de la ciudadanía (Benedicto, 2002: 41).

La ciutadania es defineix no solament pels drets que s'hi associen, sinó amb relació a l'exercici d'aquests drets. Els drets cal tenir-los reconeguts socialment, conèixer-los i exercir-los, tres fases per arribar a ser una realitat social. Per això, convé adquirir recursos per a l'exercici de la ciutadania, així com disposar d'espais i condicions per entrenar-se a ser actors del seu propi recorregut vital. És clar que donar la possibilitat de protagonisme als joves és arriscar-se que desafiïn els valors dominants, posin en dubte l'estructura política i deixin en evidència les contradiccions de la societat. De fet, l’amenaça és mútua, perquè precisament institucionalitzar la participació pot acabar convertint-se en una modalitat de control social. Com definir, aleshores, el paper que la joventut desenvolupa o ha de desenvolupar amb relació a les responsabilitats envers la comunitat? D'entrada, rebutjant interpretacions de la ciutadania que passen per l'ensinistrament de "bons ciutadans" que només promouen la conformitat i el respecte de les normes, és a dir, que promouen el que és civisme. Aquesta és una qüestió que no es resol únicament per la part que correspon als joves, és necessari un compromís actiu dels poders públics per tal que arribar a estar interessats i preocupats per la gestió d'allò públic no hagi de ser contradictori amb el ple gaudi de la condició juvenil. Es tracta més aviat de donar veu i protagonisme als joves perquè per si mateixos estableixin les seves responsabilitats polítiques. Es podrà elaborar discursos polítics propis dels joves en la mesura que els joves tinguin alguna possibilitat de ser escoltats, potser també per participar en la solució dels seus problemes. Contràriament, si continuen sense 
disposar d'aquest espai, es pot continuar tendint a refugiar-se en l'esfera privada i no implicant-se a l'esfera colllectiva.

Una altra perspectiva relacionada amb l'autonomia és la que planteja l'estudi de la transició a la vida adulta i que la defineix "com a procés social d’adquisició, enclassament i emancipació dels joves des de la pubertat fins al pas a un domicili d'ús propi" (Casals, 2004: 123). Des de la sociologia de la transició s'identifiquen components i pressupòsits bàsics de la transició a la vida adulta, així com la diversitat i les tendències dominants, per finalment identificar quines tendeixen cap a processos d'exclusió social. Els components de la transició els constitueixen el pas de l'escola al treball, la inserció professional i la configuració familiar (que inclou l'autonomia econòmica, l'autonomia funcional i de domicili propi), però

la transición no es sólo el tránsito de la escuela al trabajo, sino, más bien, un proceso complejo desde la adolescencia social hacia la emancipación plena, a la vida adulta: un proceso que incluye la formación escolar y sus trayectorias dentro de la "escuela de masas", la formación en contextos no formales e informales, las experiencias prelaborales, la transición profesional plena y los procesos de autonomía familiar (Casal, 1996: 298).

La transició es pot entendre com l'encreuament resultant les constriccions socials i les eleccions individuals, el resultat de creuar oportunitats i decisions. Casal aporta arguments que ho reforcen quan valora que "la transición es analizable como conjunto articulado de acciones de sujeto en torno a la formación de expectativas de futuro, estrategias, toma de decisiones y usos particularistas de los recursos sociales" (Casal, 1996: 299). Es descriuen cinc tipologies de transició, les tres últimes són les tipologies considerades emergents: lèxit precoç, les trajectòries obreres, les trajectòries desestructurades (bloqueig en la inserció i fracció de l'exclusió social), les trajectòries en precarietat (itineraris d'endarreriment de l'emancipació per la precarietat i rotació laborals) i l'aproximació successiva (ajustament continu de les expectatives i assumpció gradual de fites parcials). La modalitat de transició dominant és la d'aproximació successiva. Es tracta d'una estratègia per assolir objectius en la qual s'alternen moments de promoció i moments en què es manté allò assolit fins a tornar a poder aconseguir quelcom més d'allò del que un mateix es proposa o del que la societat pressuposa que caracteritza l'adultesa (formació, treball, família). Es 
duu a terme de manera progressiva i s'hi pretén reforçar qualsevol tendència a progressar, encara que no dugui directament a l'objectiu perseguit, però que ens beneficia perquè ens hi aproxima.

Les condicions estructurals dintre de les quals es desenvolupen les transicions a la vida adulta condicionen i limiten les eleccions individuals, encara que queda sota la responsabilitat i la capacitat individual d'afinar tant com sigui possible les decisions, així com conèixer i optimitzar els recursos existents. Si no sés conscient d'aquest marge, pot portar al que adverteix Casal amb relació als processos d'exclusió social:

Muchas veces, las opciones a tomar por parte de estos jóvenes no son congruentes entre sí y conducen al sujeto a replantear expectativas y tomar otras determinaciones. Muchas veces, la misma complejidad implica diferir opciones y definir prácticas que podrían ser equivocadas o erráticas (Casal, 1996: 313).

En canvi, dintre de la imperant tendència psicologista, que aconsegueix desenfocar l'anàlisi estructural i la percepció que els individus en tenen, provoca que focalizando los problemas y sus agentes responsables, el poder hace parecer que dicha problemàtica tiene sus orígenes en los individuos, en algunos grupos atípicos o en el mal funcionamiento de las instituciones [... ]. El sistema social queda bien librado, al menos en este nivel discursivo (Marcial, 2006: 21).

Es troben exemples quotidians en l'abordatge de diverses problemàtiques socials com en el consum de drogues (es criminalitza el subjecte però no es qüestiona a fons l'estructura que beneficia i que fa possible el consum), o l'anomenat fracàs escolar (fracassa el subjecte o el sistema educatiu?) o en l'atur (mai no es tenen prou formacions o competències transversals), entre altres exemples.

Sense posar en dubte que la transició escola-treball és probablement la vessant de més rellevància i l'emancipació familiar i constitució d'una nova llar també és un element d'importància, cal tenir present que de transicions en podem trobar moltes més, que han de ser tingudes en compte per evitar els perills associats a la priorització exclusiva de només aquestes tres dimensions transicionals. Un primer perill consisteix a produir una certa estandardització de les respostes a les necessitats juvenils adultes quan potser, en canvi, caldria no perdre de vista altres dimensions: la dimensió cognitiva, la dimensió afectiva i la dimensió relacional, que també esdevenen clau dins la perspectiva d'una 
plena emancipació juvenil. Convé continuar repensant allò que com a educadors permeti un treball en què no sessencialitzi la joventut en trets tan marcats com limitants i que permeti al jovent transitar vers una vida adulta en molts aspectes complementaris.

\section{El fonament històric del mite: promoure l'autonomia en el segle XXI}

Des d'abans del segle xıx, amb l'inici i desenvolupament del capitalisme s'ha anat configurant un escenari global en què sestableixen cada cop més connexions polítiques, socials i, especialment, econòmiques. Viure en un món globalitzat exalta allò que és comú arreu dels països que dominen econòmicament i relativitza les particularitats del context local. Un context marcat per la globalització que implica unes condicions de vida determinades. Com també cal tenir en compte l'impacte dels canvis tecnològics, econòmics i socials sobre els processos d'emancipació juvenil.

La manera com circula la informació i envaeix l'espai privat és alguna de les demostracions de poder dels mitjans de comunicació. Especialment a través de la televisió i cada cop més a través de la xarxa, tres o quatre dècades després de l'entrada de la ràdio i la televisió, la influència del que transmeten i retransmeten, els mitjans de comunicació participen d'una percepció particular de la realitat que es viu. "La intensidad sensorial de los medios es tan potente que provoca el embotamiento de la conciencia y de la racionalidad. La saturación de estímulos visuales y sonoros anestesia la consciencia” (Ferrés, 2008: 80). Notícies a tota hora, que recullen quantitat de desgràcies arreu del món, notícies en tal volum que cal triar-ne una cada dia perquè en l'àmbit social hi pugui haver un consens, un punt de referència imposat pels titulars, sobre allò que cal que concentri totes les mirades, enceti totes les converses i alimenti el fantasma de l'opinió pública com si tots els criteris fossin unificables o el de la majoria el més vàlid.

Un altre factor que cal tenir en compte és el de la societat de l'abundància o del consumisme. La satisfacció sistemàtica i quasi immediata de totes les necessitats materials bàsiques i superficials són el nostre pa de cada dia des de fa molt més de trenta anys, tot i que en una evolució cada cop més vertiginosa. Publicitat, centres comercials, identificació d'ideals de vida en el confort físic i 
el luxe cada cop menys exclusiu constitueixen un context determinat. La rellevància del tema del consum és cada cop més central i deriva d'una determinada organització politicoeconómica. L'actual model econòmic fomenta l'individualisme i el culte a la llei del més fort, s'imposa sobre altres àmbits de la vida social i els organitza al seu voltant. És un model que sotmet els individus a l'amenaça constant de quedar exclòs, en atur i marginat. Alhora, els mateixos individus reben un bombardeig quotidià de missatges incitant el desig, "la incitación al deseo es constante, y el apremio para satisfacerlo de manera inmediata es cada vez mayor" (Ferrés, 2008: 53), la qual cosa provoca una recerca de la satisfacció fictícia a través de béns i serveis amb la promesa d'oferir una sortida al sentiment d'insatisfacció i que alhora el perpetua en una espiral insaciable. La joventut es veu condicionada per aquesta doble tensió que assenyala extrems oposats. Els i les joves estan bombardejats d'ofertes consumistes, llençats a una carrera per obtenir ingressos i estan sovint avesats a trobar poques motivacions alternatives. Es conformen sovint amb l'oferta televisiva que els convida a la pornografia sentimental i a despullar de privacitat qualsevol àmbit de la vida. Tal com planteja Ferrés: "Es un problema que un buen número de personas se sientan tan cómodas en la sociedad del espectáculo como para no echar en falta nada más" (Ferrés, 2008: 35). Una oferta que no va més enllà del ser i existir a través i per la feina que aporta un sou i que dóna poder adquisitiu.

Les tecnologies de la informació i la comunicació (TIC) comporten canvis més enllà de les eines tècniques que ofereixen. Es tracta de l'efecte que produeixen o que poden arribar a produir en l'espai social. Portat a l'extrem, els avantatges que ens aporten les TIC es poden arribar a veure "como una nueva divinidad de la que se espera la satisfacción de las necesidades y la solución de los problemas" (Ferrés, 2008: 29). Però, tal com adverteix Ferrés, caldrà concebre-les "a un tiempo como paisaje y como espejismo, como instrumento que reivindicar y como fetiche que denunciar" (Ferrés, 2008: 21). Perquè les TIC poden compensar o bé reforçar les limitacions humanes depenent de l'ús que sén faci i de l'accés que sén disposi. Per començar, perquè allò vehiculat per una tecnologia no en garanteix l'eficàcia comunicativa i pel que s'ha d'aprendre a usar-les plenament

probablemente, uno de los factores que más contribuye a impedir la revolución de las nuevas tecnologías es, junto a las presiones del poder, el hecho de 
no haberlas asumido en su especificidad. [... E El cine, en sus orígenes, era sólo teatro filmado, y la televisión, radio con bustos parlantes (Ferrés, 2008: 32).

El canvi profund i veritable es produirà a través de l'apropiació d'aquestes TIC. En aquest sentit, l'estudi de Tapscott, considerat un "profeta de la revolució digital", ofereix conceptes clau sobre l'anàlisi que fa dels canvis de perspectives vitals i acció social derivats de les noves tecnologies. Tapscott destaca com progressivament s'imposa la cultura de la interacció en comptes de la cultura de la instrucció, ja que el ciberespai permet viure i provar experiències prèvies al món real i adult, com sobrevenen canvis en la psique, com la ment sexercita amb diferents identitats per cercar i construir-ne una de nova i particular $i$ com els aprenentatges i l'educació han de reorganitzar-se al voltant de l'element central: un subjecte interactiu que cal orientar però que autoelabora el saber. Tapscott es mostra força optimista sobre les possibilitats que els mitjans digitals ofereixen a la jove generació. Adopta una actitud entusiasta, que exalta les conseqüències positives de l'espai virtual. Caldria, però, confrontar-hi la saturació d'informació i la poca operativitat amb què encara s'infrautilitzen aquests mitjans. La generació que domina i s'apropia d'aquests mitjans, almenys tal com descriu Tapscott, encara s'està formant. Podem ja veure avui com els més joves redueixen el temps d'adaptació i s'enfronten a menys dificultats per incorporar les eines digitals respecte als més adults. Però la joventut encara no ha après a destriar de la sobreoferta; pensem sovint en clau d'acumular i retenir coneixements que volem sistematitzar i filtrar, més que no pas procurar un fluir i adaptar-se més àgilment, encara que calgui desprendre's d'una part o renunciar a copsar el conjunt. Si prenem la metàfora del "navegar per Internet", sembla que encara anem a rem, per controlar-ne de prop els corrents que ens arrosseguen, en comptes de lliscar a la cresta de l'onada a l'estil surfista, més arriscat però potser més dinàmic $i$ innovador per afavorir les repercussions que aquest camp de proves ens podria ajudar a traslladar i tant de bo a revolucionar l'espai social.

Probablement aquesta possibilitat pot emergir de l'educació i del treball amb joves, d'afavorir els aprenentatges en l'entorn de les TIC, de redefinir-ne l'ús i molt notablement amb les possibilitats que ofereix Internet. Una xarxa que permet fer circular la informació pot també establir noves formes de relació, noves possibilitats de trobada, d'intercanvi i de coneixement. Internet ens permet l'accés a qualsevol base de dades. Aquesta accessibilitat, i el consegüent 
excés d'informació, ha creat una nova necessitat per a l'educació; ja no ens preocupa tant quant aprenem, sinó com aprenem i, sobretot, amb quin objectiu aprenem. L'objectiu principal de l'educació passa per abastir els seus destinataris amb eines per analitzar amb un criteri propi tota la informació a la qual accedeixen. En aquest sentit, l'educació se centra a acompanyar i monitoritzar el desenvolupament de l'individu en tant que autònom i competent en el context social que habita.

\section{El laberint del minotaure o l'actual mercat laboral}

Pérez Islas elabora una reflexió entorn de les tres institucions en què es desenvolupa el procés de producció de nous membres de la societat, que configuren la dimensió juvenil amb les relacions que sestableixen entre si, entre la família, l'escola i el treball. Si bé trobem en aquest triangle clàssic tres institucions que han tingut el seu protagonisme en aquest àmbit, hi ha diverses consideracions que assenyalen un desequilibri en el pes real de cadascuna.

Simó (2008), en el seu article titulat "Les transicions a la vida adulta en el context de la globalització", planteja com la família es veu condicionada per l'actual mercat laboral: "en un context en què la família exerceix un paper central com a refugi dels joves davant les penúries derivades de les forces del mercat (Reher, 1998), les persones poden estar menys disposades a formar una unió i establir una nova llar" (Simó, 2008: 30). Igualment, assenyala la incapacitat de l'estat del benestar espanyol, el qual considera que no ha sabut oferir allò necessari per fer possible la conciliació familiar, com tampoc no s'ha actuat davant de les dificultats d'accés a l'habitatge. Tot plegat endarrereix i condiciona a la qüestió laboral la sortida de casa i les possibilitats de formar una nova llar.

En l'àmbit educatiu, també hi ha una perversa relació que subjuga l'educació a la qualificació laboral i sembla que opera un determinat concepte d'autonomia quan es plantegen objectius formatius i laborals. Un concepte per al qual interessa que els joves es formin i treballin perquè produeixin i consumeixin. En canvi, per a aquells que accedeixen a estudis superiors, "la perllongada educació requereix que les joves i els joves mantinguin el rol d'estudiants dependents econòmicament durant un període de temps més llarg" (Simó, 2008: 29). La família i l'educació condicionades a làmbit laboral ratifiquen el treball com 
el principal mecanisme d'integració social i, per extensió, com l'indicador d'una identitat i d'una posició d'adult.

La revolució industrial va establir les bases a partir de dos elements: els estats nació i el treball, la qual cosa generava dos tipus d'identitats: la del ciutadà i la del treballador. Quan el ciutadà es confon amb el treballador, la identitat i tots els àmbits de la persona se centren exclusivament en la seva ocupació laboral. Aquesta manera d'organitzar-se va ser vàlida durant la societat industrial. Però arribats a la societat de la informació, aquest paràmetre ja no és vàlid, ja que se centra l'exclusió en el mateix eix laboral: el que no treballa queda fora de consideració. És a dir que mentre el treball és la principal mercaderia d'intercanvi, aquesta organització ordena la societat. Quan aquest paràmetre ja no es vàlid, pels canvis del mercat laboral que fa créixer el volum de persones que ja no centren la seva identitat en la vida laboral, se centra necessàriament en altres àmbits.

El creixent nombre de persones que perden la seva identitat en perdre el lloc de treball els fa perdre igualment allò que els connecta amb el fet de sentir-se útils, és a dir, amb el fet de tenir un lloc definit i estable en el món. Aquest mecanisme d'exclusió i inclusió s'emmarca en un context de mercantilització de tots els espais socials. Tot es valora en funció dels costos, el rendiment $\mathrm{i}$ el temps. Fins i tot àmbits que haurien de mantenir-se al marge en tant que fonamentals, l'educació i la sanitat, també es tenyeixen d'aquesta competitivitat voraç.

La fi de la plena ocupació, la fi de la continuïtat en el lloc de treball al llarg de la vida, la fi de les jornades completes, caracteritzen la tendència actual de restricció del mercat de treball. Els joves sencaren a un context de treball precari que no permet configurar identitat ni "pertinença”, on el consum intenta suplir aquestes funcions. En aquest sentit, es revalora aleshores la joventut amb una constitució identitària basada en activitats extralaborals, i es configuren així "nous models de subjectivació que s'allunyen progressivament del treball com a esfera d'integració social" (Albaigés et al., 2004: 33). Caldria mesurar fins a quin punt la conveniència amb altres valors en alça, com ara poder disposar de temps per a altres activitats, facilita la normalització i acceptació de la precarietat laboral, tal com afirma Albaigés et al.

El mercat laboral actual evoluciona cap a una complexitat d'entrada i una gran facilitat i risc de sortida. Caracteritzat per una creixent dualització del 
mercat: inside (contractes indefinits i altres proteccions laborals) i outside (curta durada, males condicions, inestabilitat i poques opcions de promoció), i pel desplaçament de les persones poc qualificades, sestà reduint cada cop més l'ocupabilitat de cada cop més persones. Fins i tot per a aquells que aconsegueixen treballar, no s'ha guanyat la partida ja que "el $62 \%$ de joves-adults que viuen amb els pares treballen i podrien ser considerats econòmicament independents (Miret-Gamundi, 1997), però la majoria no gaudeix de l'estabilitat laboral que els permeti casar-se i abandonar la casa dels seus pares" (Simó, 2008: 34). Definitivament, sense propostes d'ajut i protecció, Simó prediu que "la joventut estarà abocada a llargs períodes d'incertesa i risc d'exclusió" (Simó, 2008: 48).

La precarització genera altres formes d'inserció, de transició i d'adultesa, però també genera exclusió en la mesura que n'hi ha que no poden fer aquesta adaptació, per falta de competències. Moltes vegades, la tasca que sacaba apuntant en els serveis d'inserció, i la que sense dubte es constitueix com un valuós instrument, és la d'acompanyar els qui tinguin menys capacitats per afrontar el mercat laboral actual per tal d'assumir la realitat laboral, projectar-se en el futur i elaborar estratègies per realitzar el propi recorregut fins a inserir-se laboralment. En joventut especialment es tracta sobretot de conscienciar per no deixar-se despistar pel "vel seductor de l'hedonisme consumista que els centra en el present" (Albaigés et al., 2004: 58), és a dir, gaudir que són joves i deixar per més endavant el projecte de vida. Es tracta en definitiva d'ajudar que els joves puguin fer o començar a fer per si mateixos, però no tots sols,

l'avaluació que doni sentit respecte a un projecte de vida, sigui el que sigui, la que cal recuperar, per donar al jove la possibilitat de procedir cap a accions estratègiques que el motivin a sortir del cercle de la precarietat o, si més no, a donar-li sentit en el marc d'un projecte de vida adulta coherent (Albaigés et al., 2004:58).

Hi ha una advertència d'Albaigés et al. que ens remet novament a la qüestió de l'autonomia i la dependència:

el canvi en els valors que socialitza el nou treball té profundes conseqüències psicosocials. Una de les més severes és la vulneració del vincle social a través de l'exaltació de l'individualisme i de la descalificació de la dependència mútua [... ]. Aquesta degradació de la dependència ve donada per la ideologia del parasitisme, que s'implementa a través del treball com a dispositiu de dominació 
[...], parasitisme social que el subjecte ha de procurar desmentir (Albaigés et al., 2004: 39)

i Sennet afegeix que "sin embargo, la vergüenza de ser dependiente tiene una consecuencia práctica, pues erosiona la confianza y el compromiso mutuos, y la falta de estos vínculos amenaza el funcionamiento de cualquier empresa colectiva" (Sennet, citat a Albaigés et al., 2004: 39). En la mateixa obra d'Albaigés et al. titulada Crisi del treball i emergència de noves formes de subjectivitat laboral en els joves, s'hi recull la contradicció a la qual s'enfronta el jovent quan, d'una banda, creixentment el valor del treball s'ha generalitzat com a signe d'adultesa, com a meta a assolir per part del jove en tant que condició necessària per a l'emancipació de la família i l'autodeterminació, i, d'altra banda, la feina a la qual és possible accedir és d'una qualitat cada vegada més precària, incapaç d'atorgar la seguretat i l'estabilitat necessàries per constituir-se en base d'un projecte de vida independent i sostenible.

Ambdues observacions apuntalen la tesi subjacent del que es pretén demostrar en el present article. Lluny de promoure l'autonomia en el sentit de construir éssers independents entre si mateixos, es tracta de teixir les relacions entre individus per les quals reforçar alguna mena d'organització social. Tal com assenyalen Albaigés et al. i Sennet, es considera que no es tracta de combatre la dependència, sinó d'assumir la tasca comuna i fer-la possible a través de la convenient vinculació entre actors, funcions i capacitats.

\section{La proposta: la metodologia de l'acompanyament}

Havent fet descendir dels astres el mitificat objectiu de promoure l'autonomia per emmarcar-lo entre els pilars de l'espai social en què s'hauran de moure els joves, es tracta d'identificar components d'una promoció de l'autonomia creïble en l'atenció a la joventut; un plantejament basat en l'experiència en el Servei de Seguiment, Acompanyament i Suport al Jove Extutelat i que voldria aportar elements vàlids per al conjunt de l'àmbit de la joventut. Fruit de l'experiència, sembla que per esdevenir autònom cal assumir la realitat, des de conèixer funcionaments i mecanismes socials bàsics per saber com circular socialment, a més de revisar la pròpia història, fins a entendre que es tracta de processos o itineraris i arribar a identificar què pot resultar valuós en el futur. 
Segons Cartmel i Furlong, "malgrat que els condicionants macrosocials es mantenen amb tanta o més capacitat estructurant sobre la vida de les persones com en èpoques anteriors, aquests no són percebuts com a tals" (citat a Monseny i Úcar, 2009). Cal que els joves prenguin consciència que determinats condicionants es poden entendre a un altre nivell que el personal, fins i tot més enllà del barri o la ciutat que habiten i que, per entendre-ho, hauran d'ampliar la"visió reduïda de les seves possibilitats i dels factors estructurals que els afecten” (Monseny i Úcar, 2009). Fins i tot, a més llarg termini es tracta de treballar per produir un canvi en les persones, per desenvolupar la part sana de l'actitud reactiva contra estructures socials que tant de bo es modifiquessin.

Per accedir a l'espai social, també és important que paral.lelament es duguin a terme accions encarades a acompanyar, mitjançar i ajudar a integrar la pròpia historia. Poder repassar què ha dut un jove a la situació que viu, participar del que pot arribar a fer en el futur en la mesura que es tracta d'esvair la culpabilització i la impotència per anar-se responsabilitzant. De confrontar la impossibilitat de fer-hi res a la capacitat de limitar què s'hi pot fer. En qualsevol cas, cal que sadonin en quina proporció són protagonistes del seu itinerari i afavorir la presa de consciència del que són capaços de decidir. Sense perdre de vista en quina proporció han de tenir en compte el context en què viuen, cal distingir nivells d'actuació. Hi ha qüestions que pot reclamar un individu, n'hi ha per les quals caldrà unir-se amb els veïns o el gremi o col-lectiu i n'hi ha que s'hauran d'instar amb relació a un conjunt més ampli com un ajuntament, la Generalitat, l'Estat espanyol o la Unió Europea. En qualsevol dels nivells, convindrà que els joves esdevinguin autònoms de pensament i no pas consumidors del que l'administració i el mercat prefabrica.

Com també convé que es treballi la manera com es perceben els dispositius d'ajut dins els serveis socials, massa sovint marcada per una visió jeràrquica de la ciutadania i que situa els individus que reben ajuts socials en una posició de demanda i dependència. Una posició molt més determinant que si aquests mateixos individus poden arribar a adoptar una visió horitzontal de les relacions entre ciutadans i les institucions. Treballar per aquest canvi de posicionament constitueix una tasca primordial en el treball amb joves, ja que entendre que l'administració és una forma d'organització i no pas un mecanisme per combatre sense excepció o un ens al qual demanar sense atribuir-se cap responsabilitat no fa més que fomentar l'exclusió social. Més enllà de satisfer les demandes 
o necessitats, cal vetllar per l'aprenentatge del que poden fer en el context en què viuen.

Una tercera part fonamental amb relació a les exigències socials que un cop assimilades atorguen més capacitat per fer-se càrrec de si mateix és adonar-se i concebre fins a quin punt la formació continua marcant diferències per tenir més possibilitats laborals i d'autosuficiència econòmica, en definitiva. Que la construcció d'identitats estiguin més lligades a activitats d'oci i menys a l'ocupació laboral no treu que les desigualtats socials es continuïn jugant amb la mateixa relació a la formació i l'accés al mercat de treball. Malgrat que es poden donar fenòmens com els d'atur expert (qualificats sense feina) i subocupació (contractats en tasques per sota de la formació), formar-se continua sent el mal menor escollit i pot servir per almenys poder entrar al mercat laboral. Serracant assenyala el final de l'ESO com el primer encreuament, com el punt d'inflexió que influeix el recorregut formatiu per a tota la vida. Tantmateix, pel que fa a gènere respecte a l'atur, la inversió formativa de les noies està donant fruits, troben feina més facilment ara que el mercat laboral ja no absorbeix el gruix de nois sense formació que fins ara entraven a treballar abans i en millors condicions que elles. Sovint, però, les mancances formatives culpabilitzen els individus en comptes de destapar les del sistema economicosocial establert. Se centra l'ocupabilitat en la formació que cadascú pugui acreditar i adaptar al funcionament de multinacionals que, d'altra banda, tenen l'opció de traslladar-se a països que ofereixen mà d'obra més barata i que poden comptar amb la potència en recerca i noves tecnologies ubicada igualment fora del seu territori nacional. En aquest sentit, queda en evidència la ineficàcia de la formació ocupacional fossilitzada en una oferta formativa que no està adaptada als canvis, que dóna solucions massa tard i certament limitades. Aquestes són formacions curtes, molt bàsiques i que es renoven amb dificultat, i generen bosses de persones que esperen accedir a un lloc de feina al qual aspira un gran nombre, totes amb el mateix baix nivell de preparació.

Hi ha qui valora donar continuïtat a la formació quan el que es voldria treballar és una forma de "desocupació encoberta". També sobserva una reducció de l'efecte de promoció dels títols acadèmics, però sense haver-ne obtingut cap es genera una exclusió difícil de compensar. En aquest sentit, es confronten teories de la reproducció, entenent que es reprodueixen les classes socials perquè les classes amb més poder adquisitiu fan estudis més llargs i les classes amb 
menys recursos fan itineraris més curts. En canvi, s'hi contraposen les teories de la sociologia de l'acció, en les quals pren més rellevància el "joc de les eleccions" dels individus. Ambdós aspectes compten i, anàlisis sociològiques a banda, en el treball directe amb joves cal continuar incentivant la màxima formació possible al llarg de la joventut, tot i que més formació no significa més formació teòrica o universitària, però sí acreditada per certificacions professionals vàlides per a l'accés al món laboral.

Un cop plantejat el context, la història i la importància de la formació, moltes vegades no successivament sinó simultàniament, cal elaborar el projecte. Convé triar objectius concrets enmig de la desorientació. Lluny de convocar a l'activisme juvenil propi d'algunes propostes en nom de la promoció de l'autonomia i contra la qual Alzinet reivindica els menjadors de pipes, expressant-se contra la creença que un temps organitzat $\mathrm{o} \mathrm{amb}$ intencions pedagògiques serà més convenient que un temps en què els i les joves puguin dedicar-se a activitats improductives o fins i tot avorrir-se de gust, cal marcar fites i la manera d'arribar-hi. Tot plegat suposa estimular la consciència, impulsar la presa de decisions $\mathrm{i}$ induir a l'assaig/error. Potser, fins i tot, no tant saber què s'ha de fer, sinó saber fer amb el "no-saber", de transmetre als joves que no es pot saber què convé en cada cas, quan han de decidir una formació, un objectiu laboral o el moment d'independitzar-se, sinó que cal anar provant i aprendre sobre la marxa. Treballar per un entrenament en la presa de decisions suposa no saber prèviament el resultat, sinó entendre que cal escollir, renunciar al conjunt de les possibilitats per fer-ne possible alguna.

És clar que caldrà convocar-los a tot plegat, i poder oferir de fer-ho acompanyats, per exemple, a través d'un seguiment educatiu. Disposar d'un testimoni extern al recorregut propi sovint permet que un mateix comprovi i reconegui els mèrits aconseguits $i$ les dificultats afrontades $i$ constitueix un mecanisme que permet acabar integrant la capacitat d'avaluar i redirigir el projecte. En aquest sentit, Berga, en acabar la tesi sobre la transició per transgressió, destaca l'escolta com a mecanisme per incidir positivament sobre fenòmens socials. Cal valorar la importància de sentir que algú entén i et pot explicar que hi és i no estàs sol o sola, saber que algú entén allò que t’angoixa i t’ajuda a posar-hi paraules.

Trobem components de l'autonomia més enllà de l'àmbit educatiu o assistencial. Cal considerar un nivell en què tècnics de joventut $i$ altres professionals 
que treballen amb joves tenen, $i$ han de tenir, elements $i$ criteris per incidir en les polítiques, programes i propostes legislatives entorn dels joves i la seva promoció de l'autonomia. Aquesta part de l'atenció no es desenvolupa de cara als joves, però promoure l'autonomia de forma conseqüent és també mantenir un posicionament polític i elaborar una reflexió pròpia sobre polítiques i programes de joventut. Les polítiques de joventut s'haurien de concebre en una estructura resistent i flexible, que s'adapti a les transformacions pròpies d'uns destinataris en metamorfosi constant i sobretot per evitar que solucions provisionals siguin precisament les que cronifiquin el problema pel qual havien estat concebudes. Paradoxalment, promoure polítiques específiques de joventut pot produir un bucle sense sortida, ja que probablement genera una visió fragmentada de la població per franges d'edats. Per tant, cal no perdre de vista que, en joventut, concebre lleis i polítiques específiques per als joves respon a la necessitat de disposar d'un mecanisme provisional mentre s'assoleix l'objectiu últim i veritable d'arribar a fer-se prescindible en la mesura que es podrien abordar transversalment, ja que sovint es tracta de problemes que afecten el conjunt de la societat.

Actuar contra els processos d'exclusió social o fins i tot promoure el canvi és una forta juguesca per al futur. Reguillo planteja que oferir sortides als joves és també oferir fonts de sentit i es pregunta en veu alta qui els ofereix esperances. Hom s'atreveix a provar en la perspectiva de guanyar alguna cosa, d'esperar la millora o el benestar. Més enllà de l'advertiment de les dificultats, caldrà transmetre motivació i una mínima confiança que alimenti l'esforç i esvaeixi la tristor o el temor a l'adversitat. Cal, doncs, contagiar la inquietud, el desig i l'interès imprescindible per tal de mitjançar entre el jove i el món a l'hora d'inventar i desenvolupar projectes de vida. Facilitar la trobada oferint coneixements sobre el món i partint de l'experiència vital i els conflictes que plantegi cada jove. La tasca de l'educadora social pot simultàniament resoldre certs conflictes i provocar-ne de nous, perquè forma part de l'aprenentatge trencar els esquemes i despertar la inquietud.

\section{Conclusions}

L'autonomia és un concepte que convé revisar prèviament a disposar-se a desenvolupar un treball en l'àmbit de la joventut. El procés segons el qual hom 
aprèn a triar $\mathrm{i}$ adoptar les seves normes en consonància amb el context que habita i els objectius que s'imposa és un procés complex i difícil de copsar. Tal com s'ha abordat al llarg de la reflexió, no es pot simplificar entenent-la com l'aboliment de la dependència. L'autonomia suposa i requereix lligams i suports més forts i sòlids en l'adultesa autònoma que en la joventut depenent. Tampoc es pot reduir a l'emancipació que socialment es prodiga i s'exigeix progressivament a l'edat. No es pot obviar el procés que també es juga sobre la identitat i la subjectivitat, la ciutadania i la participació o el necessari procés d'apoderament, així com considerar-la des de la perspectiva de la transició.

Cal emmarcar la promoció de l'autonomia en el context de la globalització, del rol central del consum i les tecnologies de la informació i la comunicació. Una societat i uns mecanismes socials que alhora inciten al desig sense límit i amenacen d'exclusió. Una societat en què els antics paràmetres trontollen. Una societat, en definitiva, en la qual deixa de ser vàlida la identitat amb relació al treball i en la qual el mercat laboral es va constituint en forma de laberint del minotaure modern, on és difícil l'entrada i facil la sortida.

La proposta pràctica en sintonia amb el qüestionament del concepte d'autonomia gira entorn d'establir un vincle per preparar el jovent per a la vida adulta tot ajudant-lo a assumir la realitat, elaborar el seu projecte, portar-lo a terme i fer-ho acompanyat. Es tracta de combinar la transmissió de mecanismes d'inserció social amb fomentar l'actitud crítica envers els mecanismes d'exclusió social. Alhora, posar-los alerta i que disposin d'elements per preservar-sén, així com fer-los partícips del canvi. L'experiència demostra que hi ajuden elements com ara comptar amb un professional de referència, tenir un espai i motiu de relectura de la pròpia història i disposar-se en el futur a gaudir de la presa de decisions i responsabilitat pròpies. Es tracta, en definitiva, de redimensionar el concepte d'autonomia per combatre la il.lusió d'un estat definitiu i global en què la persona s'instal.laria una vegada per totes. És un principi regulador que guia l'acció i l'orienta en la justa mesura, sense creure-hi exageradament i entenent que significa en el moment actual i per a cadascú. 


\section{Bibliografia}

Albaigés, A.; Sisto, V.; Román, J. A. (2004). Crisi del treball i emergència de noves formes de subjectivitat laboral en els joves. Colllecció Aportacions, núm. 24. Barcelona: Secretaria de Joventut.

Benedicto, J.; Morán, M. L. (2002). La construcción de una ciudadanía activa entre los jóvenes. Consultat a <http://www.injuve.es/contenidos.item.actio n?id=1022963768 menuId=2104203924> (06/01/2012).

Berga, A. (2006). Adolescència femenina $i$ risc social. Un estudi d'itineraris biogràfics i estratègies culturals des d'una perspectiva de gènere. Col.lecció Estudis, núm. 21. Barcelona: Secretaria de Joventut.

Brunet, I. [dir.] (2001). Joves i transició al mercat laboral. Barcelona: Pòrtic Biblioteca Universitària.

CASAL, J. (1996). Modos emergentes de transición a la vida adulta en el umbral del siglo XXI: aproximación sucesiva, precariedad y desestructuración. Consultat a: <http://dialnet.unirioja.es/servlet/articulo?codigo $=761453>$ $(06 / 01 / 2012)$.

De Paula, V. (2003). Estrategias de empowerment en trabajo social. Buenos Aires - Mèxic: Grupo Editorial Lumen Hvmanitas.

Feixa, C. (2001). Generació @. La joventut al segle XXI. Col+lecció Aportacions, núm. 12. Barcelona: Secretaria de Joventut.

Feliu, J. (2008). "Impacte dels videojocs: mites i pràctiques". Revista Papers de Joventut, núm. 103, p. 24-25.

Ferrés, J. (2008). La educación como industria del deseo. Un nuevo estilo comunicativo. Barcelona: Editorial Gedisa.

Grimal, P. (1997). Diccionario de mitología griega y romana. Buenos Aires: Paidós.

Meirieu, P. (1996). Frankenstein Pédagogue. Issy-les-Moulineaux: EST Editeur.

Monseny, M.; Úcar, X. (2009). El paper del tècnic de joventut davant els riscos que dificulten l'emancipació juvenil. Primer Congrés Internacional Joventut i Societat: "Joventut i risc. Unes relacions ineludibles?". Girona.

Romaní, O. (2004). Las drogas. Sueños y razones. Barcelona: Ariel. 
Simó, C. (2008). Les transicions a la vida adulta en el context de la globalització. Col+lecció Aportacions, núm. 35. Barcelona: Observatori Català de la Joventut.

Soler, P. (2005)."Les polítiques de joventut a Catalunya durant el període democràtic". Educació i Història: Revista d'Història de l'Educació, núm. 8. Societat d'Història de l'Educació dels Països de Llengua Catalana, p. 283-307.

Tapscotт, D. (1998). Growing Up Digital: The rise of the Net Generation. Nova York: McGraw-Hill. 